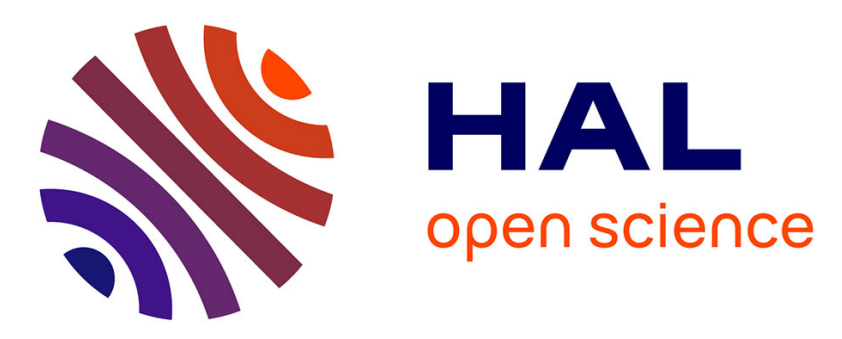

\title{
The transcriptional regulation of the glyoxylate cycle in SAR11 in response to iron fertilization in the Southern Ocean
}

\author{
Sara Beier, Maria J Galvez, Veronica Molina, Géraldine Sarthou, Fabien \\ Quéroué, Stephane Blain, Ingrid Obernosterer
}

\section{To cite this version:}

Sara Beier, Maria J Galvez, Veronica Molina, Géraldine Sarthou, Fabien Quéroué, et al.. The transcriptional regulation of the glyoxylate cycle in SAR11 in response to iron fertilization in the Southern Ocean. Environmental Microbiology Reports, 2015, 7 (3), pp.427-434. 10.1111/1758-2229.12267. hal-01130266

\section{HAL Id: hal-01130266 \\ https://hal.sorbonne-universite.fr/hal-01130266}

Submitted on 11 Mar 2015

HAL is a multi-disciplinary open access archive for the deposit and dissemination of scientific research documents, whether they are published or not. The documents may come from teaching and research institutions in France or abroad, or from public or private research centers.
L'archive ouverte pluridisciplinaire HAL, est destinée au dépôt et à la diffusion de documents scientifiques de niveau recherche, publiés ou non, émanant des établissements d'enseignement et de recherche français ou étrangers, des laboratoires publics ou privés. 


\title{
The transcriptional regulation of the glyoxylate cycle in SAR11 in response to iron fertilization in the Southern Ocean
}

\author{
Sara Beier, ${ }^{1 * \ddagger \ddagger}$ María J. Gálvez, ${ }^{1,2 \ddagger}$ Veronica Molina, ${ }^{3}$ Géraldine Sarthou, ${ }^{4}$ \\ Fabien Quéroué,, ${ }^{4,5,6}$ Stephane Blain ${ }^{1}$ and Ingrid Obernosterer ${ }^{1}{ }^{1} C N R S$, \\ Sorbonne Universités, UPMC Univ Paris 06, Laboratoire d'Océanographie \\ Microbienne (LOMIC), Observatoire Océanologique, F-66650, Banyuls/mer \\ France. \\ ${ }^{2}$ Graduate program in Oceanography, Department of Oceanography, University \\ of Concepción, Chile. ${ }^{3}$ Departamento de Biología, Facultad de Ciencias \\ Naturales y Exactas, Universidad de Playa Ancha, Avda. Leopoldo Carvallo 270, \\ Playa Ancha, Valparaíso, Chile. \\ ${ }^{4}$ LEMAR-UMR CNRS UBO IRD 6539, Technopole Brest Iroise, Place Nicolas \\ Copernic, Plouzané F29280, France. ${ }^{5}$ Institute for Marine and Antarctic Studies, \\ University of Tasmania, Hobart, Tas 7001, Australia. \\ ${ }^{6}$ Antarctic Climate \& Ecosystems Cooperative Research Centre, University of \\ Tasmania, Hobart, Tas 7001, Australia.
}

\section{Summary}

The tricarboxylic acid (TCA) cycle is a central meta- bolic pathway that is present in all aerobic organisms and initiates the respiration of organic material. The glyoxylate cycle is a variation of the TCA cycle, where organic material is recycled for subsequent assimila- tion into cell material instead of being released as carbon dioxide. Despite the importance for the fate of organic matter, the environmental factors that induce the glyoxylate cycle in microbial communities remain poorly understood. In this study, we assessed the expression of isocitrate lyase, the enzyme that induces the switch to the glyoxylate cycle, of the ubiquitous SAR11 clade in response to natural iron fertilization in the Southern Ocean. The cell-specific transcriptional regulation of the glyoxylate cycle, as determined by the ratio between copy numbers of isocitrate lyase gene transcripts and isocitrate genes, was consistently lower in iron fertilized than in highnutrient, low chlorophyll waters (by 2.4- to 16.5-fold). SAR11 cell-specific isocitrate lyase gene transcrip- tion was negatively correlated to chlorophyll a, and bulk bacterial heterotrophic metabolism. We con- clude that the glyoxylate cycle is a metabolic strategy for SAR11 that is highly sensitive to the degree of iron and carbon limitation in the marine environment.

Introduction 
Marine systems store an estimated $700 \mathrm{Pg}$ of organic carbon and its processing by aerobic heterotrophic bacterioplankton has important implications for global carbon cycling (Hedges et al., 2002). Moreover, a single group like the SAR11 clade from the Alphaproteobacteria could significantly contribute to rates of carbon processing in the ocean, considering its worldwide distribution and high abundance in marine ecosystems (Morris et al., 2002).

The switch between the tricarboxylic acid (TCA) cycle and the glyoxylate cycle may play a prominent role for the fate of carbon substrates: both cycles start with acetyl coenzyme $A$ derived from carbohydrate, fatty acid or protein degradation and share a number of common reac- tions (Berg et al., 2012). However, the glyoxylate cycle bypasses two decarboxylation steps and the coupled release of $\mathrm{CO}_{2}$ and reducing equivalents ( $\left.\mathrm{NADH}_{2}\right)$ of the TCA cycle. Instead, organic molecules are recycled and can be assimilated into cell biomass (Fig. 1).

Up-expression of the glyoxylate cycle was usually described for organisms growing on carbon sources as, i.e. acetate, if other compounds that are essential for cell growth are not available. The glyoxylate cycle is hereby used to transform these carbon substrates into organic compounds as sugars or amino acids (Kretzschmar et al., 2008; Tripp et al., 2009; Berg et al., 2012). Using metatranscriptomics, the expression of genes involved in the glyoxylate cycle were enriched in bacterioplankton communities grown under non-bloom experimental con ditions as compared with communities grown in the pres- ence of an induced phytoplankton bloom (Rinta-Kanto et al., 2012). The latter treatment was likely accompanied by higher concentrations of labile carbon sources required for bacterial growth (Rinta-Kanto et al., 2012).

Further studies that were based on transcriptional or proteomic responses in cultures suggest an upregulation of the glyoxylate cycle in the diatom Thalassiosira oceanica (Lommer etal., 2012), in members of the SAR11 clade (Smith et al., 2010) and in the gammapro- teobacterium Alteromonas macleodii (Fourquez et al., 2014) also in response to iron limitation. In these studies, the authors found an increase of the enzyme involved in the initiation of the glyoxylate cycle (isocitrate lyase) in iron-depleted cultures by means of gene transcripts (Smith et al., 2010; Lommer et al., 2012) or proteins (Fourquez et al., 2014). Iron has a fundamental role in cell biology acting as cofactor of several proteins, i.e. involved in respiration or photosynthesis (Morel and Price, 2003). A strategy to deal with iron limitation is the reduction in iron cell quota (Tortell et al., 1996). This is in part accom- plished by a lower number and expression of ironcontaining enzymes in the TCA cycle and the respiratory chain. A reduced number of iron enzymes, like cyto- chromes, in the respiratory chain has implications for the oxidation of $\mathrm{NADH}_{2}$ derived from the decarboxylation steps of the TCA cycle back to its oxidized form NAD, while providing energy in form of adenosine triphosphate (ATP) (Fourquez et al., 2014). Because ATP production via the respiration chain is inhibited during iron depletion, it may be beneficial for organisms to process organic material via the glyoxylate cycle in order to prevent the loss of carbon. Such adaptive upregulation of the glyoxylate cycle and the 
coupled decrease of respiration in response to iron and carbon limitation could noti- ceably influence the fate of organic carbon processed by bacteria.

Prominent iron-limited regions are the eastern subarctic Pacific, the eastern equatorial Pacific and the Southern Ocean, and together they occupy one third of the global ocean (Boyd, 2004). Among these, the Southern Ocean represents the largest high-nutrient, low chlorophyll (HNLC) area on earth. Natural iron fertilization was shown to occur in the wake of islands with the region around Kerguelen Island representing the largest naturally ferti- lized area (Blain et al., 2007). These regions provide con- trasting sites with respect to iron supply and bloom development that have important consequences on the production of dissolved organic matter and the related microbial heterotrophic activity (Zubkov et al., 2007; Obernosterer et al., 2008; Christaki et al., 2014).

The aim of our study was to investigate the TCA to glyoxylate cycle switch (Fig. 1) by means of isocitrate lyase gene expression in members of the abundant SAR11 clade inhabiting areas characterized by contrast- ing trophic conditions and iron availability of the Southern Ocean.

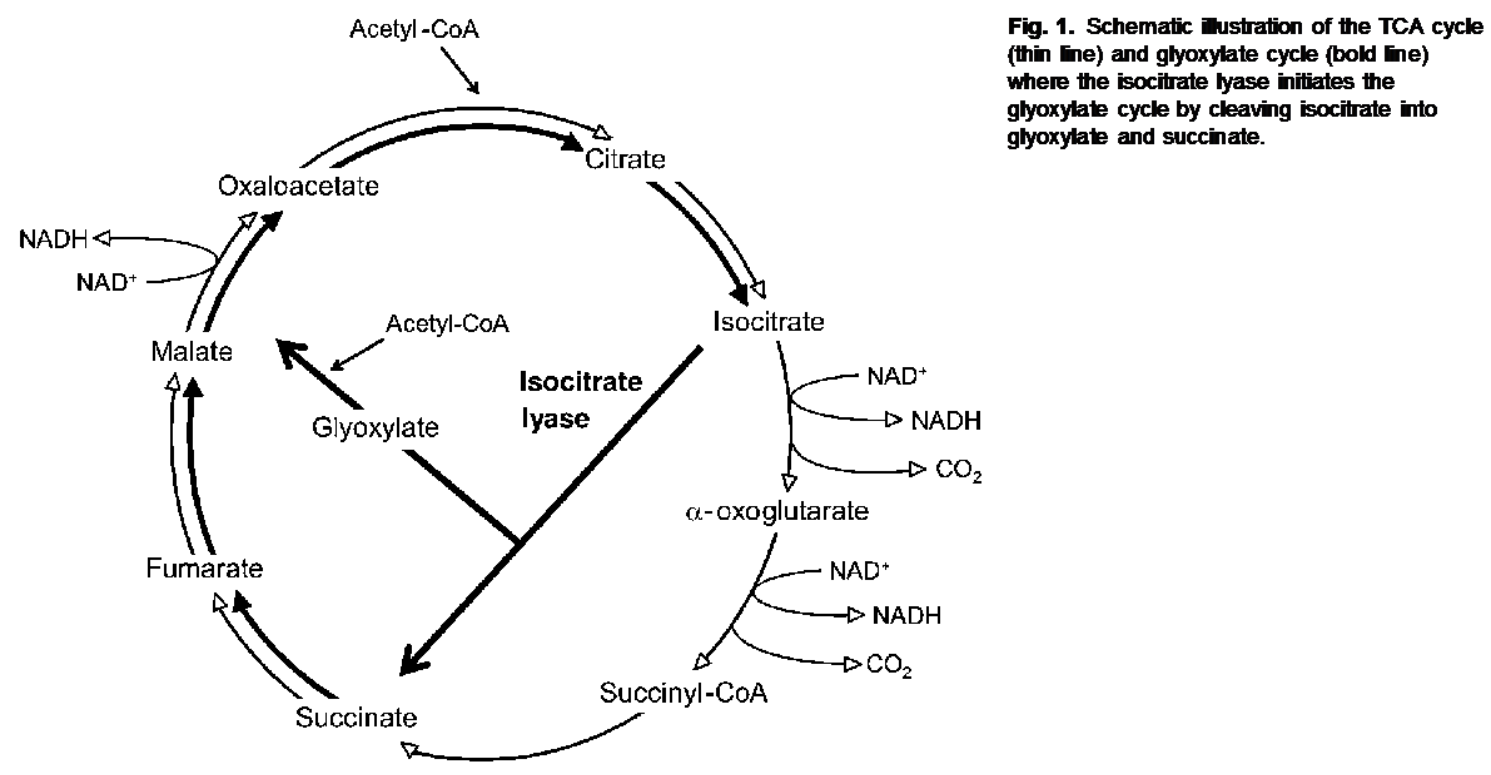




\section{Results and discussion}

\section{Environmental setting}

The region east of Kerguelen Island is characterized by intense mesoscale activity (Park et al., 2014) resulting in diverse biogeochemical responses to the input of iron-rich water masses. Concentrations of dissolved iron (DFe) were 0.08 $\mathrm{nM}$ at station R-2 (mean mixed layer), in HNLC surface waters, and they varied between 0.17 and $0.22 \mathrm{nM}$ (mean mixed layer) at the fertilized stations F-L and $\mathrm{E}-4 \mathrm{~W}$ respectively (Table S1, Quéroué et al., 2015). Concentrations of Chla were

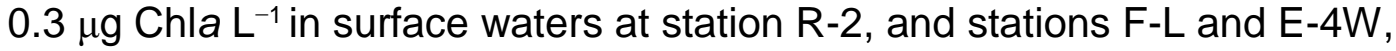
located North and South, respectively, of the Polar Front revealed intermediate (E-4W, $1.33 \mu \mathrm{g} \mathrm{Chla} \mathrm{L}^{-1}$ ) and high ( $\mathrm{F}-\mathrm{L}, 4.00 \mu \mathrm{g} \mathrm{Chla} \mathrm{L}^{-1}$ ) Chla concentrations in overall shallow mixed layers (61-38 m) (Fig. 2, Table 1). Station E-1 is located within a complex meander South of the Polar Front. No DFe data are available for station $\mathrm{E}-1$. However, this site was revisited twice in a quasi-Lagrangian manner after 1 and 4 days, and the DFe concentrations deter- mined during these visits (range 0.08 to $0.38 \mathrm{nmol} \mathrm{I}^{-1}$ in the mean mixed layer of stations E-2 and $\mathrm{E}-3)$, and more importantly the threefold higher Chla concentrations $(1.0 \mu \mathrm{g}$ $\mathrm{Chla}^{-1}$ ) than in HNLC waters clearly place station E-1 in an iron-fertilized water parcel. Despite the large variability in Chla, dissolved organic carbon (DOC) concentrations were, except for station F-L, identical among stations, probably because the labile dissolved organic matter (DOM) released by phyto- plankton was rapidly consumed. This was reflected by the large range in cell-specific bacterial heterotrophic pro- duction $\left(0.02 \mathrm{fmol} \mathrm{C}\right.$ cell $^{-1}$ day $^{-1}$ at station R-2 to 0.22 $\mathrm{fmol} \mathrm{C}$ cell $^{-1}$ day $^{-1}$ at station $\mathrm{F}-\mathrm{L}$ ), and in cell-specific bacterial respiration (range $0.88 \mathrm{fmol} \mathrm{O}_{2}$ cell $^{-1}$ day $^{-1}$ at station R-2 to $2.25 \mathrm{fmol} \mathrm{O}_{2}$ cell $^{-1}$ day $^{-1}$ at station F-L) (Christaki et al., 2014). Using Catalyzed reporter deposi- tion Fluorescence In Situ Hybridization (CARD-FISH), the abundance of SAR11 varied between 1.12 $\times 10^{8}$ and $2.79 \times 10^{8}$ cells $\mathrm{L}^{-1}$ and accounted for $36-49 \%$ of total bacterial abundance, indicating that members of the SAR11 clade were abundant at all stations (I. Obernosterer, unpubl. data). 


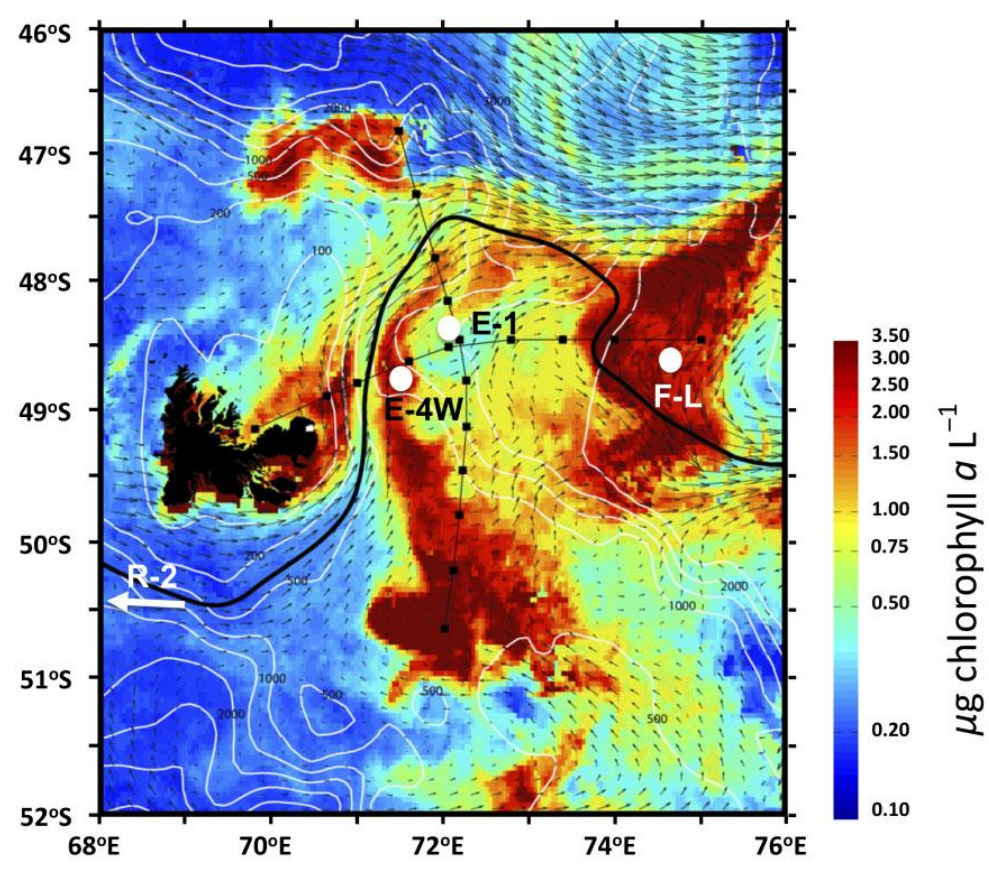

Fig. 2. Composite MODIS/MERIS satellite image of the KEOPS2 study area in OctoberNovember 2011. Shown are chlorophyll a (color scale), surface velocity fields (arrows), the Polar Front (black line), the north-south and east-west transects carried out during the cruise and the position of the three stations sampled in naturally iron-fertilized waters (stations $\mathrm{E}-1, \mathrm{E}-4 \mathrm{~W}$ and $\mathrm{F}-\mathrm{L}$ ). The reference station R-2 in HNLC waters is only indicated by an arrow as it is out of the area of the map (longitute $66^{\circ} 41.570^{\prime} \mathrm{E}$, latitute $50^{\circ} 23.370^{\prime} \mathrm{S}$ ). Map is courtesy $\mathrm{F}$. d'Ovidio and collaborators. The chlorophyll content represented on the map corresponds to the last week of the KEOPS2 cruise.

Specificity of SAR11 clade isocitrate lyase genes amplification assays

The up-expression of the isocitrate lyase gene under iron- depleted conditions could be a common trait in marine plankton (Smith et al., 2010; Fourquez et al., 2014). Our alignment analyses indicate that this gene presented a high sequences variance within the referential microbial groups analysed; therefore, we designed specific-group primers for the amplification of isocitrate lyase genes in the common and ubiquitous SAR11 clade (Table S2). Sequences $(n=200)$ derived from randomly picked clones for each of the two developed primer pairs indi- cated the specific amplification of isocitrate lyase genes derived mainly from members of the SAR11 clade (Fig. S1). The only sequence that was not affiliated to SAR11 clade isocitrate lyases (iso514_clone56) still grouped among isocitrate lyases from other organisms [closest relative from RefSeq Database (blastp search, November 2013): isocitrate lyase from Hydrocarboniphaga effusa, Gl: 494341513, e-value: 2e-16]. Nonetheless, possible rare amplification events of isocitrate lyase gene sequences that were not derived from members of the SAR11 clade would still allow testing for transcription of isocitrate lyase in response to iron limitation.

The construction of degenerated primers (Table S2) in order to amplify isocitrate lyase genes from possibly all members of the SAR11 clade may lead to unequal ampli- fication of isocitrate lyase genes derived from different SAR11 strains.

However, we assumed transcription rates [ratio of ribonucleic acid: deoxyribonucleic acid (RNA:DNA) copy numbers] in different SAR11 strains to be equal or at least similar in response to the environmental conditions at each sample site, because these different strains are phylogenetically closely related and should function in a similar way. If transcription rates among different strain 
are similar, the overall transcription rate is only marginally influenced by different amplification efficiencies of the strain-specific isocitrate lyase genes (Table S3). SAR11 in our sample sites was dominated by a single OTU (at $97 \%$ similarity of the $16 \mathrm{~S}$ rRNA gene) accounting for $60-66 \%$ of all SAR11 sequences (Landa, 2013).

Transcription patterns of the isocitrate lyase gene

We compared the cell specific transcription of the isocitrate lyase gene in members of the SAR 11 clade by estimating the ratio of gene copy numbers in RNA and DNA extracts from the four selected stations (Fig. 3). Lowest gene transcription was detected for the iron- fertilized station F-L, while stations E-4W and E-1 that were also affected by iron fertilization revealed intermedi- ate transcription levels. The highest gene transcription was observed at the irondepleted HNLC station R-2, being 16.5-fold increased compared with station F-L (Fig. 3). The performed analysis of variance revealed a highly significant influence of the chosen stations on the transcription of the isocitrate lyase gene among members of the SAR11 clade $(P=0.0003)$. Post hoc pairwise analy- ses indicated significant differences between station R-2 and stations F-L and E-4W (Table 2). Even if only four stations were investigated, these cover a large range in responses to iron availability and connected environmen- tal parameters of the isocitrate lyase gene expression. Accordingly, our data demonstrate a pronounced tran- scriptional upregulation of the glyoxylate cycle in SAR11 at sites that feature iron depletion, but are simultaneously characterized by limited amounts of bioavailable DOM as indicated by low values for chlorophyll $a$ and bacterial heterotrophic metabolism (Fig. 4). Our results obtained in the Southern Ocean extend previous observations in experimental studies on the regulation of the isocitrate 


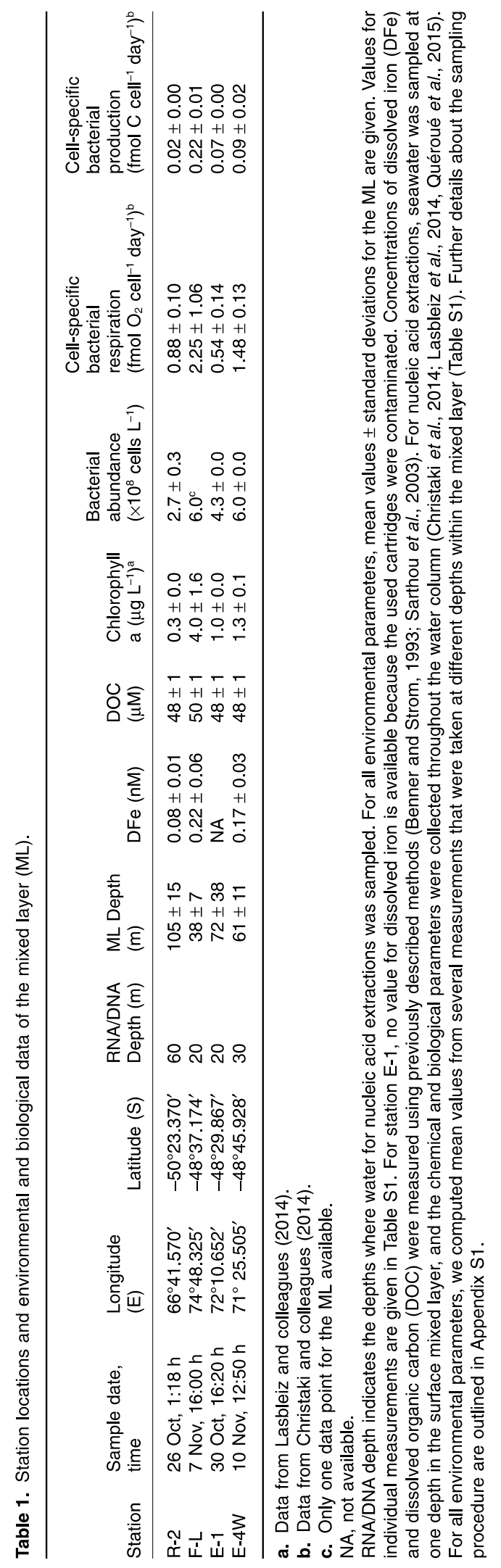




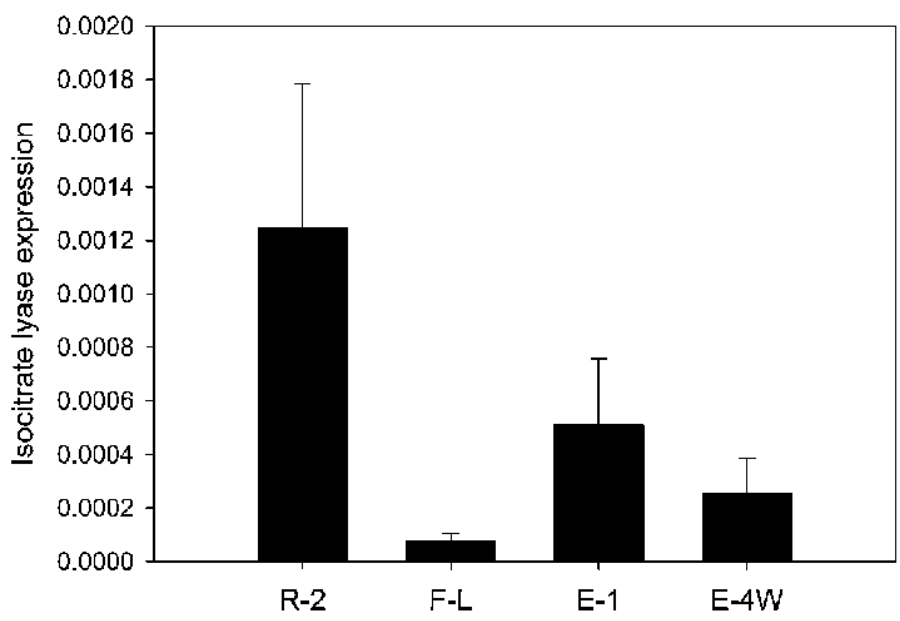

\begin{abstract}
Fig. 3. Isocitrate lyase gene expression. Quantification of the isocitrate lyase gene expression estimated by the ratio between isocitrate lyase copy numbers per nanogram RNA and isocitrate lyase copy numbers per nanogram DNA. Both values were obtained by a quantitative PCR approach. Enor bars indicate the standard deviation of the RNA DNA ratios estimated from the three ratios as described in Appendix S1. Further methodological detaits are outined in Appendix S1. Information about the developed primers that target the isocitrate lyase gene of Pelagibacter-fike organisms is given in Table S2 and Fig. S2.
\end{abstract}

lyase gene expression in response to either iron (Smith et al., 2010; Lommer et al., 2012; Fourquez et al., 2014) or DOM supply via phytoplankton exudates (Rinta-Kanto et al., 2012). The large range of expression patterns observed in the present study (up to 16.5-fold) compared with the response of the SAR11 member Candidatus Pelagibacter ubique (Cand. P. ubique) to iron limitation in culture [1.6 fold-change, (Smith et al., 2010)] may in our case indicate a coregulation mediated simultaneously via iron and DOM supply. Heterotrophic bacterial production was indeed co-limited by iron and organic carbon in the study region (Obernosterer et al., 2014).

Recent observations from culture and environ- mental studies suggest a potential role of light in the regulation of the isocitrate lyase gene. SAR11 cells as proteorhodopsin-containing organisms (Giovannoni et al., 2005a) could increase the transcription of the isocitrate lyase gene in the light analogously to Dokdonia sp. MED 134 (Palovaara et al., 2014). Diel patterns in the expres- sion of the isocitrate lyase gene in members of the SAR11 clade in natural bacterial communities in the coastal Pacific ocean support this idea (Ottesen et al., 2013, Palovaara et al., 2014). By contrast, the organic carbon- starved Cand. P. ubique did not reveal any changes in the expression of the isocitrate lyase gene in response to light/dark regimes (Steindler et al., 2011). Another light- driven process was recently proposed by Carini and colleagues (2014). These authors have shown that $C a n d$. $P$. ubique cannot use exogenous thiamin (vitamin $\mathrm{B}_{1}$ ), an essential coenzyme for the TCA cycle, and that this member of SAR11 is auxotrophic for the thiamin precursor 4-amino-5-hydroxymethyl-2methylpyrimidine (HMP), a molecule that is degraded by light. The enhanced avail- ability of HMP in the dark could trigger the isocitrate lyase expression. To which extent light influences the expres- sion of the isocitrate lyase gene clearly merits further investigation. 
Regulation of the glyoxylate cycle expression was described in detail on the posttranscriptional level (Laporte et al., 1989; White, 2007; Berg et al., 2012). However, specifically Cand. P. ubique was shown to feature a posttranscriptional regulation system of the glyoxylate shunt that differs from that described in other bacteria and is based on a riboswitch driven by cellular glycine concentrations (Tripp et al., 2009; Tripp, 2013). The increased transcript abundance of isocitrate lyase genes in response to iron depletion in cultured Cand. P. ubique (Smith et al., 2010) as well as culture independent data from our study imply that this gene is also regulated on the transcriptional level. Even though an upregulation of isocitrate lyase was found under iron- and carbon- limited conditions, this gene cannot be considered a general stress response gene since it is not upregulated under nitrogen- and sulfur-limited conditions (Smith, 2011; Smith et al., 2013). To the best of our knowledge, the mechanism underlying transcriptional regulation of the isocitrate lyase gene in Pelagibacter sp. has so far not been described.

Table 2. Differences in isocitrate lyase gene transcription among the sampled stations were tested for significance by applying analysis of variance (ANOVA) with post-hoc pairwise comparisons (Tukey test).

\begin{tabular}{ll}
\hline Sample site & Pairwise $P$-value \\
\hline E-4W/E-1 & 0.1625586 \\
F-L/E-1 & 0.0023862 \\
R-2/E-1 & 0.1717241 \\
F-L/E-4W & 0.0504277 \\
R-2/E-4W & 0.0068310 \\
R-2/F-L & 0.0002238 \\
\hline
\end{tabular}

The overall $P$-value for the ANOVA was 0.000288 and pairwise posthoc $P$-values (Tukey test) of the ANOVA comparing isocitrate lyase gene expression at different sample sites are displayed in the table. Further details about the performed statistical analyses are given in Appendix S1. 


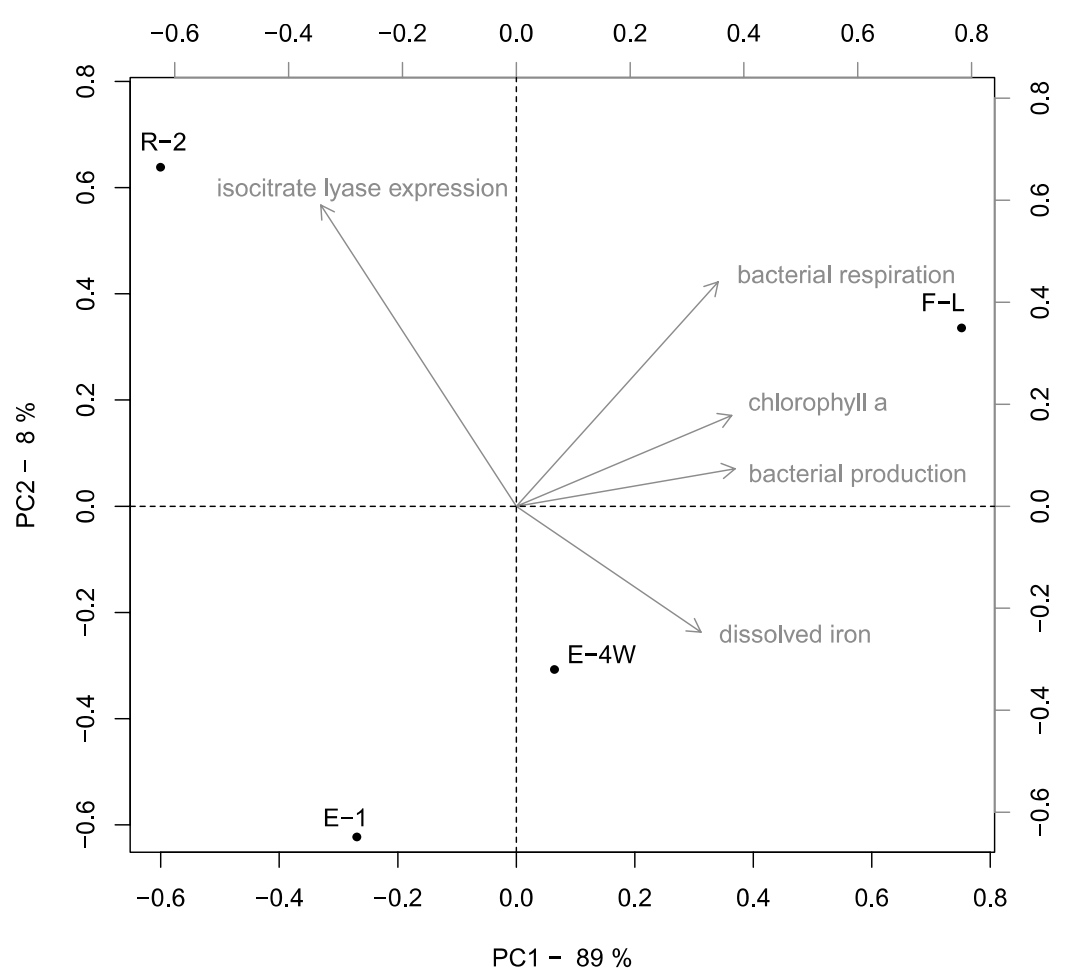

Fig. 4. Principal component analyses (PCA). In order to estimate principal components, we used the non-linear iterative partial least square (NIPALS) algorithm (Wold, 1966) implemented in the ade4 package of the R program (Chessel et al., 2004). NIPALS analyses allow the extraction of principal components from a dataset that contains missing variables, as it was the case for our data. In order to estimate the contribution of the two first principal components to the total variance, we estimated in total four principal components, as it would be the case in an analog PCA. The variables for isocitrate lyase expression, bacterial respiration and bacterial production represent cell-normalized values.

Multivariate analyses point to a strong regulation of the isocitrate lyase gene by DFe, Chla and bacterial activity, with varying degrees of influence (Fig. 4). Concentrations of DFe and Chla are indicators of the amount of bioavailable iron, while bacterial production is an indicator of bioavailable DOM. In the Southern Ocean, the iron and carbon cycles are tightly coupled; thus, the SAR11 isocitrate lyase gene expression pattern we observed in the present study points to a response to the availability of both iron and organic carbon. The direct effect of iron on bacterial heterotrophic metabolism was shown experi- mentally. Bacterial cells grown under iron-limited condi- tions were shown to contain lower iron quota (Tortell et al., 1996; Fourquez et al., 2014). This could in part be a consequence of the reduced number of iron-containing enzymes within the TCA cycle and the respiratory chain (Fourquez et al., 2014). Channeling organic substrate through the glyoxylate cycle could be a strategy to avoid loss of carbon atoms (Fig. 1) if iron concentrations are scarce and NADH-dependent ATP production via the respiration chain is inhibited. The upregulation of the glyoxylate cycle that may not only occur in SAR11 entails that a smaller fraction of carbon molecules per cell are respired to $\mathrm{CO}_{2}$. However, also the limited availability of labile carbon substrates likely causes a decrease in res- piration at the HNLC site. Probably both mechanisms cause the negative correlation between DFe and single cell respiration along the principal component analysis axis (Fig. 4). 
The otherwise streamlined genome of Pelagibacter sp. (Giovannoni et al., 2005b) contains all genes for the glyoxylate cycle. This feature could represent an ecologi- cal advantage in vast parts of the oceans where iron is a limiting nutrient and SAR11 dominates the bacterioplankton, including our study sites where the cosmopolitan sub clade la was dominant (Landa, 2013). Moreover, marine strains unrelated to the geo- graphically ubiquitous distributed SAR11 subclade la (HIMB59 and HIMB114) isolated from non-iron-limited coastal zones of the tropical North Pacific lack the isocitrate lyase gene (Grote et al., 2012). Also, this gene was absent in members of the freshwater sister clade LD12 (S. Bertilsson, pers. comm.). Even though fresh- water systems contain iron in the micromolar range, this nutrient can be limiting for microbial metabolism (Vrede and Tranvik, 2006). The higher concentrations and quali- tative characteristics of DOM in freshwater systems might lead to a stronger iron-binding capacity and result in the lower availability of iron. Whether enhanced iron con- centrations in freshwater and marine systems and the lack of the full glyoxylate cycle are related remains to be investigated.

Based on our study, recent metatranscriptomic approaches (Rinta-Kanto et al., 2012; Rivers et al., 2013) and culture-dependent studies (Smith et al., 2010; Lommer et al., 2012; Fourquez et al., 2014), we propose isocitrate lyase as a key indicator gene of the glyoxylate cycle whose transcription is sensitively coupled to envi- ronmental changes in marine environments associated with iron and DOM availability. Future studies that inves- tigate in more detail regulation mechanisms of this gene in specific response to iron and/or DOM supply under varying light regimes may help to better understand and predict the processing of carbon through the TCA or glyoxylate cycle.

\section{Acknowledgements}

We thank the captain and the crew of the RV Marion Dufresne and the chief scientist $\mathrm{B}$. Quéguiner for their support during the KEOPS2 cruise. The help of M. Landa in the collection of seawater for nucleic acid analyses is greatly appreciated. J. Caparros excellently performed DOC analy- ses. The colour products for the Kerguelen area were pro- duced by Ssalto/Duacs and CLS with support from Cnes. Three anonymous reviewers greatly improved a previous version of the manuscript. We thank Y. Park, M. Zhou and F. d'Ovidio for providing Fig. 2. M.J. Galvez was supported by the LIA MORFUN, the ECOS-SUD project PROMO (C12U01) and CONICYT-PCHA/Magíster Nacional/2014-221320590. The KEOPS2 project received financial support from the CNRS-INSU-LEFE-CYBER, the ANR-10-BLAN- 0614 and the IPEV. 


\section{References}

Benner, R., and Strom, M. (1993) A critical-evaluation of the analytical blank associated with doc measurements by high-temperature catalytic-oxidation. Mar Chem 41: 153160.

Berg, J.M., Tymoczko, J.L., and Stryer, L. (2012) Biochem- istry, 7th edn. New York, NY, USA: W. H. Freeman and Company.

Blain, S., Queguiner, B., Armand, L., Belviso, S., Bombled, B., Bopp, L., et al. (2007) Effect of natural iron fertilization on carbon sequestration in the Southern Ocean. Nature 446: 1070-U1.

Boyd, P. (2004) Ironing out algal issues in the southern ocean. Science 304: 396-397. Carini, P., Campbell, E.O., Morre, J., Sanudo-Wilhelmy, S.A., Thrash, J.C., Bennett, S.E., et al. (2014) Discovery of a SAR11 growth requirement for thiamin's pyrimidine precur- sor and its distribution in the Sargasso Sea. Isme J 8: 1727-1738.

Chessel, D., Dufour, A.B., and Thioulouse, J. (2004) The ade4 package - I: one-table methods. R-News 4: 5-10. Christaki, U., Lefèvre, D., Georges, C., Colombet, J., Catala,

P., Courties, C., et al. (2014) Microbial food web dynamics during spring phytoplankton blooms in the naturally iron- fertilized Kerguelen area (Southern Ocean). Biogeosci Discuss 11: 6985-7028.

Fourquez, M., Devez, A., Schaumann, A., Guéneuguès, A., Jouenne, T., Obernosterer, I., and Blain, S. (2014) Effects of iron limitation on growth and carbon metabolism in oceanic and coastal heterotrophic bacteria. Limnol Oceanogr 59: 349-360.

Giovannoni, S.J., Bibbs, L., Cho, J.C., Stapels, M.D., Desiderio, R., Vergin, K.L., et al. (2005a) Proteorhodopsin in the ubiquitous marine bacterium SAR11. Nature 438: 82-85.

Giovannoni, S.J., Tripp, H.J., Givan, S., Podar, M., Vergin, K.L., Baptista, D., et al. (2005b) Genome streamlining in a cosmopolitan oceanic bacterium. Science 309: 12421245.

Grote, J., Thrash, J.C., Huggett, M.J., Landry, Z.C., Carini, P., Giovannoni, S.J., and Rappe, M.S. (2012) Streamlining and core genome conservation among highly divergent members of the SAR11 clade. Mbio 3: e00252-12.

Hedges, J.I., Baldock, J.A., Gelinas, Y., Lee, C., Peterson, M.L., and Wakeham, S.G. (2002) The biochemical and elemental compositions of marine plankton: a NMR perspective. Mar Chem 78: 47-63.

Kretzschmar, U., Khodaverdi, V., Jeoung, J.-H., and Goerisch, H. (2008) Function and transcriptional regulation of the isocitrate lyase in Pseudomonas aeruginosa. Arch Microbiol 190: 151-158.

Landa, M. (2013) Lien entre matière organique dissoute et diversité des communautés bactériennes hétérotrophes marines. PhD thesis. University Pierre et Marie Curie. Paris. France. 
Laporte, D., Stueland, C., and Ikeda, T. (1989) Isocitrate dehydrogenase kinase phosphatase. Biochimie 71: 1051- 1057.

Lasbleiz, M., Leblanc, K., Blain, S., Ras, J., Cornet-Bathaux, V., He'lias Nunige, S., and Que guiner, B. (2014) Pig- ments, elemental composition (C, N, P, Si) and stoichiometry of particulate matter, in the naturally iron fertilized region of Kerguelen in the Southern Ocean. Biogeosciences 11: 8259-8324.

Lommer, M., Specht, M., Roy, A.-S., Kraemer, L., Andreson, R., Gutowska, M.A., et al. (2012) Genome and low-iron response of an oceanic diatom adapted to chronic iron limitation. Genome Biol 13: R66.

Morel, F.M.M., and Price, N.M. (2003) The biogeochemical cycles of trace metals in the oceans. Science 300: 944- 947.

Morris, R.M., Rappe, M.S., Connon, S.A., Vergin, K.L., Siebold, W.A., Carlson, C.A., and Giovannoni, S.J. (2002) SAR11 clade dominates ocean surface bacterioplankton communities. Nature 420: 806-810.

Obernosterer, I., Christaki, U., Lefevre, D., Catala, P., and Van Wambeke, F. (2008) Rapid bacterial mineralization of organic carbon produced during a phytoplankton bloom induced by natural iron fertilization in the Southern Ocean. Deep-Sea Res Part 2 Top Stud Oceanogr 55: 777-789.

Obernosterer, I., Fourquez, M., and Blain, S. (2014) Fe and C co-limitation of heterotrophic bacteria in the naturally ferti- lized region off Kerguelen Islands. Biogeosci Discuss 11: 15733-15752.

Ottesen, E.A., Young, C.R., Eppley, J.M., Ryan, J.P., Chavez, F.P., Scholin, C.A., and DeLong, E.F. (2013) Pattern and synchrony of gene expression among sympatric marine microbial populations. Proc Natl Acad Sci USA 110: E488- E497.

Palovaara, J., Akram, N., Baltar, F., Bunse, C., Forsberg, J., Pedrós-Alió, C., et al. (2014) Stimulation of growth by proteorhodopsin phototrophy involves regulation of central metabolic pathways in marine planktonic bacteria. Proc Natl Acad Sci 11: E3650-E3658.

Park, Y.-H., Durand, I., Kestenare, E., Rougier, G., Zhou, M., d'Ovidio, F., et al. (2014) Polar Front around the Kerguelen Islands: an up-to-date determination and associated circulation of surface/subsurface waters. J Geophys Res Oceans 119: 6575-6592.

Quéroué, F., Sarthou, G., Planquette, H.F., Bucciarelli, E., Chever, F., van der, Merwe, et al. (2015) High variability of dissolved Fe at the vicinity of the Kerguelen Islands (South- ern Ocean). Biogeosciences Discussions, KEOPS 2 special issue 12: 231-270.

Rinta-Kanto, J.M., Sun, S., Sharma, S., Kiene, R.P., and Moran, M.A. (2012) Bacterial community transcription pat- terns during a marine phytoplankton bloom. Environ Microbiol 14: 228-239.

Rivers, A.R., Sharma, S., Tringe, S.G., Martin, J., Joye, S.B., and Moran, M.A. (2013) Transcriptional response of bathypelagic marine bacterioplankton to the Deepwater 
Horizon oil spill. ISME J 7: 2315-2329.

Sarthou, G., Baker, A.R., Blain, S., Achterberg, E.P., Boye, M., Bowie, A.R., et al. (2003) Atmospheric iron deposition and sea-surface dissolved iron concentrations in the eastern Atlantic Ocean. Deep-Sea Res Part -Oceanogr Res Pap 50: 1339-1352.

Smith, D.P. (2011) The proteomic and transcriptomic responses to iron, sulfur, and nitrogen limitation in the abundant marine bacterium Candidatus Pelagibacter ubique. $\mathrm{PhD}$ thesis, Oregon State University, Corevallis, USA. https://ir.library.oregonstate.edu/xmlui/bitstream/ handle/1957/26077/SmithDanielP2011.pdf?sequence=1.

Smith, D.P., Kitner, J.B., Norbeck, A.D., Clauss, T.R., Lipton, M.S., Schwalbach, M.S., et al. (2010) Transcrip- tional and translational regulatory responses to iron limitation in the globally distributed marine bacter- ium Candidatus Pelagibacter ubique. PLoS ONE 5: e10487.

Smith, D.P., Thrash, J.C., Nicora, C.D., Lipton, M.S., Burnum-Johnson, K.E., Carini, P., et al. (2013) Proteomic and transcriptomic analyses of 'Candidatus Pelagibacter ubique' describe the first $\mathrm{P}$-II-independent response to nitrogen limitation in a free-living alphaproteobacterium. Mbio 4: e00133-12.

Steindler, L., Schwalbach, M.S., Smith, D.P., Chan, F., and Giovannoni, S.J. (2011) Energy starved Candidatus Pelagibacter ubique substitutes light-mediated ATP production for endogenous carbon respiration. PLOS ONE 6: e19725.

Tortell, P.D., Maldonado, M.T., and Price, N.M. (1996) The role of heterotrophic bacteria in iron-limited ocean ecosys- tems. Nature 383: 330-332.

Tripp, H.J. (2013) The unique metabolism of SAR11 aquatic bacteria. J Microbio/ 51: 147-153.

Tripp, H.J., Schwalbach, M.S., Meyer, M.M., Kitner, J.B., Breaker, R.R., and Giovannoni, S.J. (2009) Unique glycine-activated riboswitch linked to glycine-serine auxotrophy in SAR11. Environ Microbiol 11: 230-238.

Vrede, T., and Tranvik, L.J. (2006) Iron constraints on plank- tonic primary production in oligotrophic lakes. Ecosystems 9: 1094-1105.

White, D. (2007) The Physiology and Biochemistry of Prokaryotes, 3rd edn. New York, NY, USA: Oxford Univer- sity Press.

Wold, H. (1966) Estimation of principal components and related models by iterative least squares. In Multivariate Analysis. Krishnaiah, P. (ed.). New York, NY, USA: Aca- demic Press, pp. 391-420.

Zubkov, M.V., Holland, R.J., Burkill, P.H., Croudace, I.W., and Warwick, P.E. (2007) Microbial abundance, activity and iron uptake in vicinity of the Crozet Isles in November 2004-January 2005. Deep-Sea Res Part li-Top Stud Oceanogr 54: 2126-2137.

\section{Supporting information}


Additional Supporting Information may be found in the online version of this article at the publisher's web-site:

Fig. S1. Phylogenetic tree containing isocitrate lyase sequences from cultured reference sequences (RefSeq) and PCR amplicons from primer pairs Iso448f/Iso799r (Iso799_cloneXX, orange letters) and Iso448f/Is0514r (Iso541_cloneXX, blue letters). The tree was constructed by calculating a backbone tree with the reference protein sequences using SATE versus 2.2.5. (Treeestimator: FASTTREE, Aligner: MAFFT, merger: MUSCLE, model GTR + G20, default settings) (Edgar, 2004; Katoh et al., 2005; Liu et al., 2009; Price et al., 2010). Sequences of PCR amplicons were integrated a posteriori into the tree using the ARB program (Parsimony, partial sequence option) (Ludwig etal., 2004) and sequences derived from methylisocitrate lyase genes were used as outgroup. Alphaproteobacterial sequences are indicated by bold letters and isocitrate lyases from sequenced Pelagibacter strains are labelled in pink.

Fig. S2. Alignment of the developed primers, isocitrate lyase gene sequences from cultured strains of the SAR11 clade and sequences with high similarity to SAR11 isocitrate lyases extracted from the GOS metagenomes.

Table S1. Individual values for environmental data in the mixed layer depth that were used to calculated mean values and standard deviations given in Table 1. Table S2. Sequence information and melting temperature of developed primers.

\begin{tabular}{|c|c|c|c|c|c|}
\hline Station & $\mathrm{DOC}[\mu \mathrm{M}]$ & $\begin{array}{c}\text { Cell-specific } \\
\text { bacterial } \\
\text { respiration } \\
{\left[\mathrm{fmol} \mathrm{O}_{2} \text { cell }^{-1}\right.} \\
\left.\mathrm{d}^{-1}\right]\end{array}$ & $\begin{array}{l}\text { Chlorophyll a } \\
{\left[\mu \mathrm{g} \mathrm{L}^{-1}\right]}\end{array}$ & $\begin{array}{c}\text { Cell-specific } \\
\text { bacterial } \\
\text { production } \\
\text { [fmol C cell-1 } \\
\left.\mathrm{d}^{-1}\right]\end{array}$ & $\begin{array}{l}\text { Dissolved } \\
\text { Iron [nM] }\end{array}$ \\
\hline $\mathrm{R}-2$ & $48(40 \mathrm{~m})$ & $0.77(20 \mathrm{~m})$ & $0.32(20 \mathrm{~m})$ & $0.018(20 \mathrm{~m})$ & $0.09(40 \mathrm{~m})$ \\
\hline $\mathrm{R}-2$ & $47(70 \mathrm{~m})$ & $1.41(40 \mathrm{~m})$ & $0.32(40 \mathrm{~m})$ & $0.023(40 \mathrm{~m})$ & $0.08(70 \mathrm{~m})$ \\
\hline $\mathrm{R}-2$ & $48(100 \mathrm{~m})$ & $0.90(80 \mathrm{~m})$ & $0.27(80 \mathrm{~m})$ & $0.019(80 \mathrm{~m})$ & \\
\hline $\mathrm{R}-2$ & & $0.43(100 \mathrm{~m})$ & $0.23(100 \mathrm{~m})$ & $\begin{array}{l}0.016 \\
(100 \mathrm{~m})\end{array}$ & \\
\hline F-L & $49(20 \mathrm{~m})$ & $1.50(10 \mathrm{~m})$ & $2.88(10 \mathrm{~m})$ & $0.220(10 \mathrm{~m})$ & $0.26(20 \mathrm{~m})$ \\
\hline F-L & $51(35 \mathrm{~m})$ & $3.00(20 \mathrm{~m})$ & $5.12(35 \mathrm{~m})$ & $0.210(35 \mathrm{~m})$ & $0.17(35 \mathrm{~m})$ \\
\hline E-1 & $49(20 \mathrm{~m})$ & $0.62(15 \mathrm{~m})$ & $1.00(20 \mathrm{~m})$ & $0.074(20 \mathrm{~m})$ & NA \\
\hline E-1 & $49(40 \mathrm{~m})$ & $0.60(20 \mathrm{~m})$ & $0.96(40 \mathrm{~m})$ & $0.069(40 \mathrm{~m})$ & \\
\hline E-1 & $47(70 \mathrm{~m})$ & $0.40(65 \mathrm{~m})$ & & & \\
\hline E-4W & $49(20 \mathrm{~m})$ & $1.57(30 \mathrm{~m})$ & $1.38(10 \mathrm{~m})$ & $0.11(10 \mathrm{~m})$ & $0.20(20 \mathrm{~m})$ \\
\hline E-4W & $49(30 \mathrm{~m})$ & $1.39(50 \mathrm{~m})$ & $1.40(40 \mathrm{~m})$ & $0.09(40 \mathrm{~m})$ & $0.16(40 \mathrm{~m})$ \\
\hline E-4W & $47(70 \mathrm{~m})$ & & $1.22(70 \mathrm{~m})$ & $0.08(70 \mathrm{~m})$ & $0.15(70 \mathrm{~m})$ \\
\hline
\end{tabular}

Table S2. Sequence information and melting temperature of developed primers.

$\begin{array}{llll}\text { Primer sequence }\left(5^{\prime}-3^{\prime}\right) & \text { melting } & \text { sequence position in the } \\ & \text { temperature } & \begin{array}{l}\text { isocitratelyase gene of } \\ \text { Candidatus Pelagibacter }\end{array} \\ \end{array}$




\begin{tabular}{llll}
\hline & & ubique HTCC1062 \\
\hline Iso448f & GGTGAAGCHGGDTTTGGWGG & $53.8-57.9$ & 448 \\
Iso799r & AGAGGTYTWGCWTAYGCRCCTT & $51.1-56.7$ & 799 \\
Iso514r & GCKGCWGGNGTTCACTTTGA & $51.8-55.9$ & 514 \\
\hline
\end{tabular}

Table S3. Demonstration of possible biases to QPCR data that can be introduced by unequal amplification efficiency of degenerated primers.

Table S4. Sequence information for clones obtained from the primer pair Iso448f/Iso514r.

Appendix S1. Experimental procedures

\section{Appendix S1: Experimental procedures}

\section{Sample collection}

Seawater samples were collected during the natural iron fertilization experiment KEOPS2 (Kerguelen Ocean and Plateau Compared Study 2, Oct. 8 - Nov. 30 2011) in the Indian sector of the Southern Ocean. The French Polar Institute (Institut Polaire Emile Victor) approved the sampling and work conducted in the study area. Four stations were chosen for the present study: One station was located in HNLC waters (Station R-2) and three stations were located in naturally iron-fertilized waters (Stations E-1, E-4W and F-L).

Seawater samples for nucleic acid extractions were collected with $12 \mathrm{~L}$ Niskin bottles mounted on a rosette equipped with a CTDO Seabird SBE911-plus. For dissolved iron (DFe) and dissolved organic carbon (DOC) analyses, samples were collected from 10 L Teflon-lined Niskin-1010X bottles mounted on a 1018 rosette system adapted for trace metal clean work. DFe concentrations $(<0.2 \mu \mathrm{m})$ were measured onboard by Flow Injection Analysis using a modified method of the Obata method (Sarthou et al., 2003). At Station E-1, the cartridge used for $0.2 \mu$ m filtration of the samples was contaminated, and therefore no results are available for this site. DOC concentrations were measured on acidified aliquots of GF/F filtered samples using a Shimadzu TOC-VCP analyzer with a Pt catalyst at $680^{\circ} \mathrm{C}$ (Benner and Strom, 1993). All DOC analyses were run in duplicate and 3-5 injections were done for each sample.

For nucleic acid extractions, seawater was sampled at one depth in the surface mixed layer (Table 1), and the chemical and biological parameters were collected throughout the water column (Christaki et al., 2014; Lasbleiz et al., 2014). For all environmental parameters we computed mean values from several measurements that were taken at different depths within the mixed layer (Table S1). 


\section{Nucleic acid sampling and extraction}

For both, DNA and RNA extractions volumes varying between $15 \mathrm{~L}$ and $30 \mathrm{~L}$ of prefiltered water ( $200 \mu \mathrm{m}$ nylon screen and $5 \mu \mathrm{m}$ Polycarbonate Isopore filters) was collected onto $0.2 \mu \mathrm{m}$ SuporPlus Membranes using a $142 \mathrm{~mm}$ filtration system (geotech equipment inc.) and a peristaltic pump. For RNA samples, the filtration procedure did not exceed 10 minutes. DNA filters were stored at $-80^{\circ} \mathrm{C}$ and to the RNA filters $10 \mathrm{ml}$ of RNA-later was added before storage at $-80^{\circ} \mathrm{C}$. All nucleic acid extractions were performed in triplicates by dividing the filter in 3 parts. DNA was extracted using the DNeasy Blood and Tissue Kit (Qiagen, Hilden, Germany). Cellular lysis was performed with Proteinase $\mathrm{K}\left(2 \mathrm{~h}\right.$ incubation, $\left.56^{\circ} \mathrm{C}\right)$ and followed by mechanical disruption using low binding zirconium beads (OPS Diagnostics, Lebanon, NJ, USA). The extracted DNA was quantified using the Quant-it Picogreen dsDNA Assay (Invitrogen Life Technologies, Carlsbad, CA, USA). RNA was extracted using the NucleoSpin ${ }^{\circledR}$ RNA Midi kit (Macherey-Nagel, Düren, Germany). Filters stored in RNA later were defrosted, removed from the RNA later solution, refrozen in liquid nitrogen and shattered using a mortar. The obtained 'powder-like' filter-pieces were added together with low binding zirconium beads, (OPS Diagnostics, Lebanon, NJ, USA) to the denaturing lysis buffer supplied by the NucleoSpin ${ }^{\circledR}$ RNA Midi kit and cells were disrupted by vortexing for 2 min. The extraction with the NucleoSpin ${ }^{\circledR}$ RNA Midi kit include an on-column DNA digestion step. However, in order to ensure the absence of DNA in the sample, a PCR reaction was performed without the retrotranscription (RT) step. Samples with DNA contamination, as indicated by amplification products were treated with a second DNA digestion step using the Turbo DNA-free kit (Ambion Life Technologies, Carlsbad, CA, USA). This additional DNAse treatment was followed by purification with the RNeasy MinElute Clean Up kit (Qiagen, Hilden, Germany). The extracted RNA was quantified with the Agilent 2100 Bioanalyzer/Agilent RNA 6000 Nano Kit (Agilent, Santa Clara, CA, USA).

\section{Primer design}

We extracted 2577 bacterial sequences belonging to the isocitrate lyase protein family from the RefSeq data base. Out of these, reference sequences with a protein sequence similarity of 50\% (CD-Hit Program (Li et al., 2001)) and three sequences derived from Pelgibacter sp. (GI numbers: 91763004, 71083928, 27377566) as cultured representatives for the SAR11 clade were used for a seed alignment. An initial alignment was produced by the Mafft v7.012 software (homolog option, (Katoh et al., 2005)). This alignment was then manually refined using the secondary structure of the isocitrate lyase from M. tuberculosis (Protein Data Bank [PDB] Entry 1f61, chain A).

Sequences from uncultured marine bacteria were extracted from the GOS metagenome (Rusch et al., 2007) via the CAMERA Portal (Seshadri et al., 2007). For this purpose GOS data (all open reading frames) were queried by a tBLASTN search using three isocitrate lyases from Pelgibacter sp. (GI numbers: 91763004, 
$71083928,27377566)$ and 13 further reference sequences from the remaining RefSeq isocitrate lyases (35\% protein sequence similarity, CD-Hit program). All RefSeq protein data and all retrieved GOS sequences with an isocitrate lyase from Pelagibacter sp. as top hit (translated to protein sequence, min 300 amino acids, evalue $\leq 5.72 \times 10^{-67}$ ) were aligned to the previously described seed alignment by HMMer v2.3 software (Eddy, 1998). Corresponding nucleotide sequences were aligned according to the created protein alignment and used for primer design. The primers were designed to amplify short and long regions for different applications such as Q-PCR and cloning using Primer-BLAST from NCBI (http://www.ncbi.nlm.nih.gov/tools/primer-blast/) online program with C. Pelagibacter ubique (HTCC1062) isocitrate lyase sequence as template. The primers were then manually modified in order to include GOS environmental sequences related to SAR11-like sequences and selected to have a TM close to $60^{\circ} \mathrm{C}$ and low self-complementarity (Table S2).

All primer combinations were tested for PCR using pooled DNA extracts including all stations from this study. The combination of the primer pairs Iso448f/Iso799r as well as Iso448f/Iso514r resulted in the amplification of PCR products with the expected lengths (approx. $400 \mathrm{bp}$ and $100 \mathrm{bp}$, respectively).

To test the amplification specificity of the primers, PCR products were subjected for cloning and subsequent sequencing. Hereby reaction were prepared in $20 \mu \mathrm{l}$ volumes containing $1 \times$ PCR buffer (Invitrogen Life Technologies, Carlsbad, CA, USA), $2.5 \mathrm{mmol} \mathrm{l}^{-1} \mathrm{MgCl}_{2}, 100 \mathrm{nmol} \mathrm{L}^{-1}$ of the forward and reverse primers, $200 \mathrm{mmol} \mathrm{l}^{-1}$ of each dNTP (Eurogentec, Liège, Belgium) and $0.8 \mathrm{U}$ Taq polymerase (Invitrogen Life Technologies, Carlsbad, CA, USA). Initial denaturation for $5 \mathrm{~min}$ at $94^{\circ} \mathrm{C}$ was followed by 35 cycles (Iso448f/Iso799r) or 30 cycles (Iso448f/Iso514r) of $94^{\circ} \mathrm{C}$ for $1 \mathrm{~min}, 60^{\circ} \mathrm{C}$ for $1 \mathrm{~min}$ and $72^{\circ} \mathrm{C}$ for $1 \mathrm{~min}$. A step for final elongation was at $72^{\circ} \mathrm{C}$ for $7 \mathrm{~min}$.

4 PCR reactions of each amplification were pooled and directly used for ligation into pCR $2.1^{\mathrm{TM}} \mathrm{TOPO}^{\circledR}$ vector (Invitrogen Life Technologies, Carlsbad, CA, USA) following the manufacturer's instructions. In order to remove salts from the ligation, $4 \mu \mathrm{l}$ of the reaction were dialyzed for $1 \mathrm{~h}$ at room temperature on VSWP filters (Millipore, Billerica, MA, USA, $0.025 \mu \mathrm{m}$ poresize) that were located on top of $20 \mathrm{ml} 1 \times \mathrm{TE}$ buffer ( $\mathrm{pH}$ 8) in a petridish. The dialyzed and diluted (1:1, MilliQ-water [Millipore, Billerica, MA, USA]) ligation reaction was used for cloning into electro competent One Shot TOP $10^{\circledR}$ Electrocomp ${ }^{\mathrm{M}}$ E. coli cells (Invitrogen), following the manufacturer's instructions. For both primer combinations 100 clones were picked and send for Sanger Sequencing to Macrogen (Seoul, South Korea). Sequence information is available at GeneBank under accession numbers KF991397 KF991474 (primerpair Iso448f/Iso799r) and Table S4 (primerpair Iso448f/Iso514r).

\section{Quantitative PCR}

We applied a quantitative PCR approach (Q-PCR) in order to determine isocitrate lyase copy numbers in DNA as well as RNA extracts. It turned out difficult to construct probes that would hybridize with all clone-sequences derived from 
amplification with the primer pair Iso448f/Iso799r for subsequent TaqMan Q-PCR. We instead decided to use the primer pair Iso448f/Iso514r for SYBRGreen based QPCR.

Q-PCR for DNA extracts was performed using SybrGreen PCR Core Reagents in a StepOnePlus Real-Time PCR Systems (Applied Biosystems Life Technologies, Carlsbad, CA, USA). $1 \mu \mathrm{l}$ of diluted DNA $\left(\sim 0.1 \mathrm{ng}^{-1}\right)$ was used in a final reaction volume of $10 \mu \mathrm{l}$ containing $500 \mathrm{nmol} \mathrm{L}^{-1}$ of each primer. The q-PCR reaction was performed with one cycle of $50^{\circ} \mathrm{C}(2 \mathrm{~min})$ and a denaturation step of $95^{\circ} \mathrm{C}(10 \mathrm{~min})$ followed by 40 cycles of $95^{\circ} \mathrm{C}$ for $15 \mathrm{~s}, 60^{\circ} \mathrm{C}$ for $20 \mathrm{~s}$ and $72^{\circ} \mathrm{C}$ for $20 \mathrm{~s}$. A melting curve was created subsequently by heating $95^{\circ} \mathrm{C}(15 \mathrm{~s})$ cooling down to $60^{\circ} \mathrm{C}(60 \mathrm{~s})$ and increasing temperature again gradually by $0.3^{\circ} \mathrm{C}$ steps to $95^{\circ} \mathrm{C}$. Fluorescence was measured at the elongation step and after each $0.3^{\circ} \mathrm{C}$ temperature increasing for the melting curve.

To estimate the copy numbers of isocitrate lyase transcripts a reverse transcription q-PCR was performed using the Power SYBR Green RNA-to-Ct 1-step kit (Applied Biosystems Life Technologies, Carlsbad, CA, USA). $1 \mu \mathrm{l}$ of diluted RNA (1-4 ng ul l-1) was used in a final reaction volume of $10 \mu \mathrm{l}$ containing $500 \mathrm{nmol} \mathrm{L}^{-1}$ of each primer. A reverse transcription was performed at $48^{\circ} \mathrm{C}$ for $30 \mathrm{~min}$. PCR started immediately after with 10 minutes at $95^{\circ} \mathrm{C}$, followed by 40 cycles with $95^{\circ} \mathrm{C}$ for $15 \mathrm{~s}$ and $60^{\circ} \mathrm{C}$ for $60 \mathrm{~s}$. The reaction was finalized with a melting curve as described above.

All DNA and RNA samples respectively were processed in a single qPCR run in order to obtain best comparability between the samples. Copy numbers of isocitrate lyase genes were estimated using standards with known concentration of the target gene ranging from $10^{6}$ to 10 copy numbers $\mu^{-1}$ (10-fold dilutions). The standards were obtained from clone iso514_clone23 after plasmid extraction (QIAprep Spin Miniprep, Qiagen, Hilden, Germany), plasmid stabilization (Plasmid-Safe ${ }^{\mathrm{TM}}$, Epicentre Biotechnologies, Madison, WI, USA) and linearization using the Not1 restriction enzyme (New England Biolabs, Ispwich, Massachusetts, MA, USA). Amplification efficiencies for DNA and RNA amplifications respectively were $106 \%$ and $85 \%$ respectively. Tests preceding final Q-PCR amplifications with different dilutions of template DNA and RNA demonstrated that amplifications at chosen DNA/RNA concentrations were not affected by inhibitors in the nucleic acid extracts. Isocitrate lyase copy numbers per ng nucleic acid were determined by triplicates in each extract and a single mean value per extraction was used for subsequent analyses.

\section{Data Analyses}

All sequenced members of the SAR11 clade (Pelagibacter sp.) possess a single copy of the isocitrate lyase gene and we estimated the cell specific transcription activity of the isocitrate lyase gene by calculating the ratio of gene copy number per ng RNA and gene copy number per ng DNA. Differences in isocitrate lyase gene transcription among the sampled stations were tested for significance by applying ANOVA with post-hoc pairwise comparisons (Tukey-test). Hereby we built all 9 possible ratio values by combining triplicates for RNA iscocitrate copy number and DNA isocitrate 
copy number. We, however, used only the two ratios with the lowest and the highest value and the median intermediate value as input data for the ANOVA, to not artificially increase the degree of freedom that was based on only three measurements for each, RNA and DNA copy numbers. These input data for the ANOVA were log transformed because visual inspection indicated a better fit of residuals to normal distribution after the transformation. In order to estimate principal components we used the non-linear iterative partial least square (NIPALS) algorithm (Wold, 1966) implemented in the ade4 package of the R program (Chessel et al., 2004). NIPALS analyses allow the extraction of principal components from a dataset that contains missing variables, as it was the case for our data. In order to estimate the contribution of the two first principal components to the total variance, we estimated in total 4 principal components, as it would be the case in an analog PCA.

\section{References (Appendix S1)}

Benner, R. and Strom, M. (1993) A critical-evaluation of the analytical blank associated with DOC measurements by high-temperature catalytic-oxidation. Mar Chem 41: 153-160.

Chessel, D., Dufour, A., B., and Thioulouse, J. (2004) The ade4 package - I : One-table methods. R-News 4: 5-10.

Christaki, U., Lefèvre, D., Georges, C., Colombet, J., Catala, P., Courties, C., et al. (2014) Microbial food web dynamics during spring phytoplankton blooms in the naturally iron-fertilized Kerguelen area (Southern Ocean). Biogeosciences Discuss 11: 6985-7028.

Eddy, S.R. (1998) Profile hidden Markov models. Bioinformatics 14: 755-763.

Edgar, R.C. (2004) MUSCLE: a multiple sequence alignment method with reduced time and space complexity. BMC Bioinformatics 5: 1-19.

Katoh, K., Kuma, K., Toh, H., and Miyata, T. (2005) MAFFT version 5: improvement in accuracy of multiple sequence alignment. Nucleic Acids Res. 33: 511-518.

Lasbleiz, M., Leblanc, K., Blain, S., Ras, J., Cornet-Bathaux, V., Hélias Nunige, S., and Quéguiner, B. (2014) Pigments, elemental composition (C, N, P, Si) and stoichiometry of particulate matter, in the naturally iron fertilized region of Kerguelen in the Southern Ocean. Biogeosciences Discuss 11: 8259-8324.

Li, W.Z., Jaroszewski, L., and Godzik, A. (2001) Clustering of highly homologous sequences to reduce the size of large protein databases. Bioinformatics 17: 282283.

Liu, K., Raghavan, S., Nelesen, S., Linder, C.R., and Warnow, T. (2009) Rapid and accurate large-scale coestimation of sequence alignments and phylogenetic trees. Science 324: 1561-1564.

Ludwig, W., Strunk, O., Westram, R., Richter, L., Meier, H., Yadhukumar, et al. (2004) ARB: a software environment for sequence data. Nucleic Acids Res 32: 13631371.

Price, M.N., Dehal, P.S., and Arkin, A.P. (2010) FastTree 2-approximately maximumlikelihood trees for large alignments. Plos One 5: e9490.

doi:10.1371/journal.pone.0009490 
Rusch, D.B., Halpern, A.L., Sutton, G., Heidelberg, K.B., Williamson, S., Yooseph, S., et al. (2007) The sorcerer II global ocean sampling expedition: Northwest Atlantic through Eastern Tropical Pacific. PLoS Biol 5: e77.

Sarthou, G., Baker, A.R., Blain, S., Achterberg, E.P., Boye, M., Bowie, A.R., et al. (2003) Atmospheric iron deposition and sea-surface dissolved iron concentrations in the eastern Atlantic Ocean. Deep-Sea Res I 50: 1339-1352.

Seshadri, R., Kravitz, S.A., Smarr, L., Gilna, P., and Frazier, M. (2007) CAMERA: a community resource for metagenomics. Plos Biol 5: 394-397.

Wold, H. (1966) Estimation of principal components and related models by iterative least squares. In Multivariate Analysis. Krishnaiah, P. (ed). New York: Academic Press, pp. 391-420. 